\title{
Comparison between Recent benthic foraminiferal faunas of the Porcupine Seabight and Western Approaches Continental Slope
}

\author{
JANICE F. WESTON \\ SSI Limited, Tannery House, Tannery Lane, \\ Send, Woking, Surrey GU23 7EF, U.K.
}

\begin{abstract}
Although only 1 degree of latitude apart, the South Western Approaches and Porcupine Seabight continental slopes support widely differing benthic foraminiferal faunas. The less energetic, less variable, muddier conditions of the prograding margin of the Porcupine Seabight yield foraminiferal faunas which show extremely good zonations with respect to depth and are dominated by species such as Trifarina angulosa, Gavelinopsis lobatulus and Uvigerina pygmaea. The more variable and more energetic conditions of the submarine canyons of the Western Approaches margin do not support well depth zones faunas, but assemblages which are generally dominated by more cosmopolitan and robust species, such as Cassidulina carinata, Brizalina dilatata and B.subaenariensis. Such differences may be related to factors such as a greater variability of sediment type and bottom water characteristics and a more energetic environment in the Western Approaches area.
\end{abstract}

\section{INTRODUCTION}

In terms of geomorphology, the continental slope represents a transition from continent to ocean. Environmentally, it represents the transition from highly variable physical conditions on the continental shelf to stable, invariable conditions in the deep sea at greater than $2000 \mathrm{~m}$ water depth (Rowe \& Haedrich, 1979) Menzies et al (1973) described transitional invertebrate faunas from the continental slopes of the World Ocean, which they called the "Archibenthal Transition Zone". The faunas from this zone are typified by mixtures of continental shelf and deep ocean species. However, benthic foraminiferal faunas from the continental slopes are distinct and unlike those of the deep sea at greater than $2000 \mathrm{~m}$ or the continental shelves at less than $200 \mathrm{~m}$. This paper records the results from a study of the benthic foraminiferal faunas of two areas of the European continental slope which are geographically close but totally dissimilar in physical setting: the Porcupine Seabight and Western Approaches continental slope.

\section{PHYSICAL SETTING}

Although relatively near to each other on the European continental margin, the Porcupine Seabight and Western Approaches continental slopes represent quite different environments in terms of their sedimentological and hydrographic properties. The two areas lie on the continental margin off SW England and Ireland, $1^{\circ}$ in latitude apart (Fig. 1). However, the Porcupine Seabight represents a prograding margin, while active submarine canyon erosion is taking place off the Western Approaches (Owen, 1974).

The Porcupine Seabight is a large SW-NE trending depression in the continental margin flanked by the Goban Spur to the south and the Porcupine Bank to the north (Fig. 1). In the axis of the Seabight, the floor has an inclination of $0.5-2^{\circ}$ and the shelf break occurs at, or just below, $200 \mathrm{~m}$ water depth (Day, 1959; Shepard, 1973). At approximately $50^{\circ} \mathrm{N}$, the floor of the Seabight is cut by a short submarine canyon system, the Gollum Channel System (Kenyon et al., 1978), but north of this, in the area sampled during this study, no major submarine canyons are recorded. The northern flank, formed by the Porcupine Bank, is more gently sloping and uncut by submarine canyons (Day, 1959).

In comparison, the Western Approaches continental slope is steep (average inclination $5-9^{\circ}$, Kenyon et al., 1978) and it is dissected by several large, dendritic submarine canyon systems. Two main canyon areas were explored in this study, the Whittard and Shamrock Canyons (Fig. 1). Both have a SW-NE trend, following a probable Hercynian fault trend (Kenyon et al., 1978).

The distribution of sediment types (i.e. sand, silt, mud) in the two areas is different. All 10 core-top samples from a traverse down the Porcupine Bank to the abyssal plain comprise brown silty muds and muds. Six Murray grab samples from approximately $400 \mathrm{~m}-1200 \mathrm{~m}$ just north of the axis of the Seabight and due east of Ireland contain greater proportions of sand and silt in the shallower samples than the samples from the Porcupine Bank. The steepness of the continental slope and the active submarine canyon systems of the Western Approaches area influence the occurrence of sediment types. The variety of sedimentary substrates available in such an area is illustrated by the results of a submersible dive recorded by Mart et al. (1979). Between $2000 \mathrm{~m}$ and $2650 \mathrm{~m}$ on the continental slope west of Shamrock Canyon, Mart and his co-authors record the occurrence of rock outcrops and coarse to fine grained unconsolidated sediments. Dredge samples taken from the canyon areas during this study have included sediments showing a range in grain size from pebble/gravel size to fine muds, 
and also clasts of consolidated marly sediment and chalk. Therefore, the Western Approaches area shows a greater variety and variability of sediment types than the Porcupine Seabight.

Greater variability in the Western Approaches area is also the case for the hydrographic setting of the two areas. At less than $2000 \mathrm{~m}$ water depth, the main bottom water mass in both areas is Mediterranean Water which has a core showing maximum salinity $\left(>35.6 \%_{0}\right)$ and temperature (approx. $9^{\circ} \mathrm{C}$ ), and minimum oxygen concentrations (approx. $4 \mathrm{ml} / \mathrm{l}$ ) at around $1000 \mathrm{~m}$ (Cooper, 1952). The properties of the Mediterranean Water are dependent upon the formation of dense, saline water in the eastern basins of the Mediterranean Sea and upon the amount of mixing this water undergoes as it enters the Atlantic Ocean through the Strait of Gibraltar. These factors can, and do, vary seasonally, and this means that Mediterranean Water is exceedingly variable in terms of its physical properties (Herman, 1981). Cooper (1952) gives an indication of this variability for the area west of the Celtic Sea shelf (see Fig. 2).

Such a hydrographic setting is also complicated in the Western Approaches area by other factors which are thought not to occur in the Porcupine Seabight:

1. The seasonal cascading of shelf waters on to the continental slope (Cooper \& Vaux, 1949) and/or the seasonal upwelling of deep waters (Heaps, 1980; Pingree \& Mardell, 1981).

2. The occurrence of submarine canyon currents which may be of two types:

a. Alternating vertical currents of approximately $25-35 \mathrm{~cm} / \mathrm{sec}$ (measured at $3 \mathrm{~m}$ above the sediment surface) whose alternation is related to the tidal cycle and depth (Shepard et al., 1979) or

b. Relatively infrequent and short-lived turbidity currents whose sediment-laden waters can reach

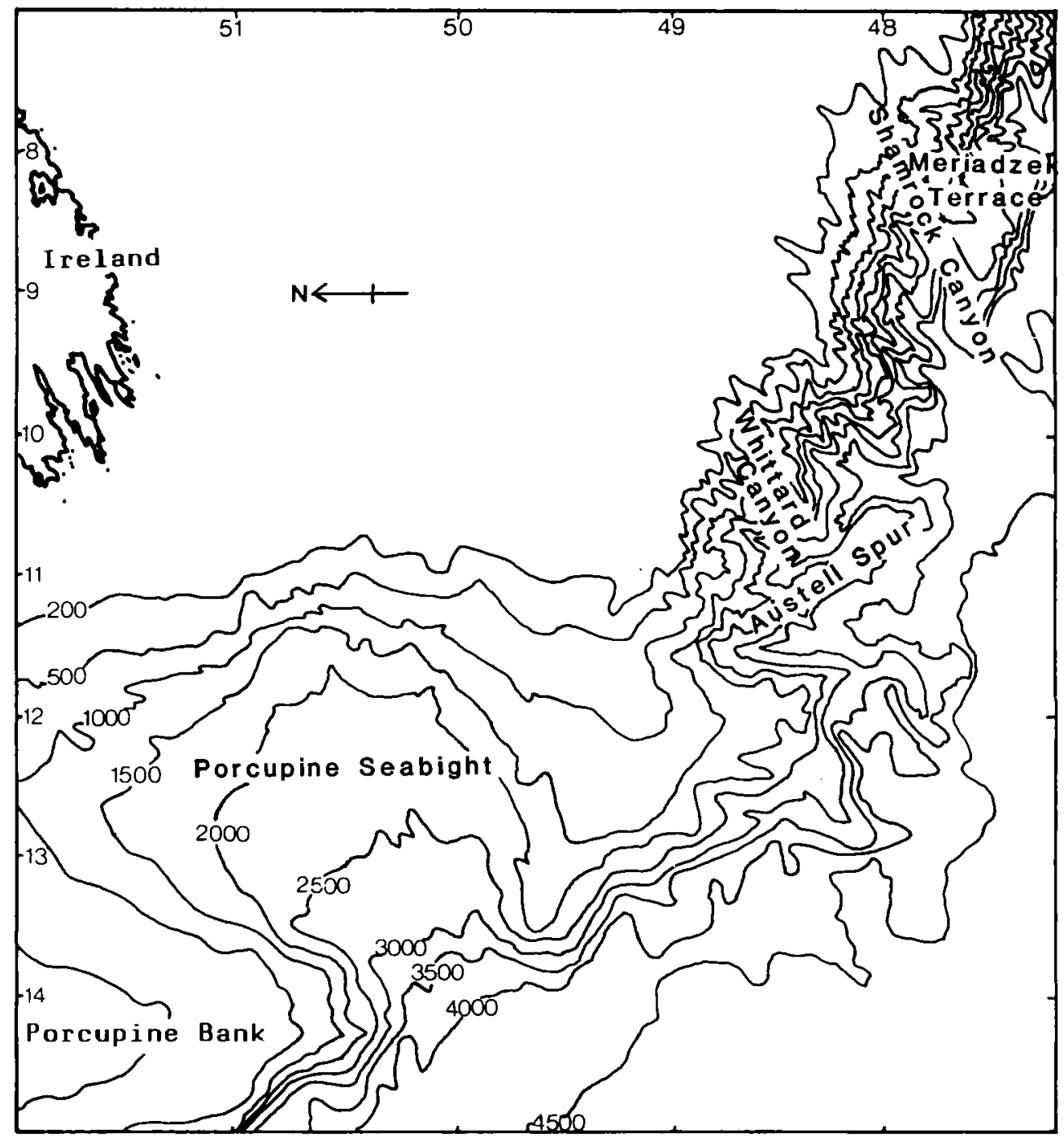

Fig. 1. Porcupine Seabight and SW Approaches continental margin. Contours in metres. 
speeds of up to $3 \mathrm{~km} / \mathrm{hr}$ (Shepard et al., 1979).

Dr. D. Hamilton of Bristol University has measured currents of 18.9 to $52.0 \mathrm{~cm} / \mathrm{sec}$ at spring equinoctial tides in Whittard Canyon at upper slope depths to $2000 \mathrm{~m}$ (pers. comm., 1981: current measurements made at $1 \mathrm{~m}$ above the sediment surface).

All these factors contribute to make the hydrographic setting in the Western Approaches area more variable and complex than that in the Porcupine Seabight.

\section{MATERIAL AND METHODS}

Porcupine Seabight - A series of six surface sediment samples $(422 \mathrm{~m}$ to $1600 \mathrm{~m})$ were collected by the author just north of the axis of the Porcupine Seabight in April 1980 (Fig. 3). These samples were taken using a Murray Grab (Weston, 1982), which collects a surface sample $10 \mathrm{~cm} \times 10 \mathrm{~cm} \times 1 \mathrm{~cm}$. This traverse is supplemented by one sample from $1130-1140 \mathrm{~m}$ taken by Drs. A. J. and E. C. Southward of the Marine Biological Association (MB A), Plymouth, which was collected using a Scottish MBA (SMBA) Box Dredge. A series of 10 samples taken by the Institute of Oceanographic Sciences, Wormley have also been studied. These represent a traverse from $510 \mathrm{~m}$ on the Porcupine Bank to $4130 \mathrm{~m}$ on the Porcupine Abyssal Plain (Fig. 3). These samples were collected using an SMBA Multiple Corer. Only those samples collected by the author were preserved on collection (in methanol) and were suitable for analysis of the living foraminiferal assemblages.

Western Approaches Margin - Samples from the Western Approaches Margin were collected by the author and by Drs. A. J. and E. C. Southward. The sampling equipment was either a Murray Grab or a $3 \mathrm{ft}$ Anchor Dredge. If the equipment used was an anchor dredge, the sample analysed is taken from surface mud which showed as little evidence of washing as possible (Weston, 1982). Samples from the Whittard Canyon cover a depth range of $255 \mathrm{~m}$ to $2400 \mathrm{~m}$ and those from the Shamrock Canyon, a depth range of $287 \mathrm{~m}$ to $1950 \mathrm{~m}$ (Fig. 3). Samples were also taken on the Meriadzek Terrace at depths between $765 \mathrm{~m}$ and $1260 \mathrm{~m}$. The Meriadzek Terrace represents a southward projection of the continental margin to the east of Shamrock Canyon (Fig. 1). The majority of samples collected in the S. W. Approaches area were preserved on collection.

A quantitative study requires that samples have not been modified by the sampling process. This infers that sample quality is affected by the type of sampling device used. The commonest causes of modification to the sample are washing during the return haul to the ship or loss of the sediment surface due to the "bow-wave" effect of the sampling equipment. Living foraminiferal assemblages collected with the sampling equipment in this study suggest that the "bow-wave" effect has not greatly modified samples. The SMBA Multiple Corer and Murray Grab are designed so that washing of the sample is unlikely to occur. Washing of samples taken by the Anchor Dredge is possible but the tough canvas collecting bag of the dredge minimises this. Only Anchor Dredge samples which showed minimal effects of washing at the time of collection are included within the quantitative analysis; others are simply used to indicate the presence or absence of a species. The presence of surface sediment in a sample is indicated by the occur-

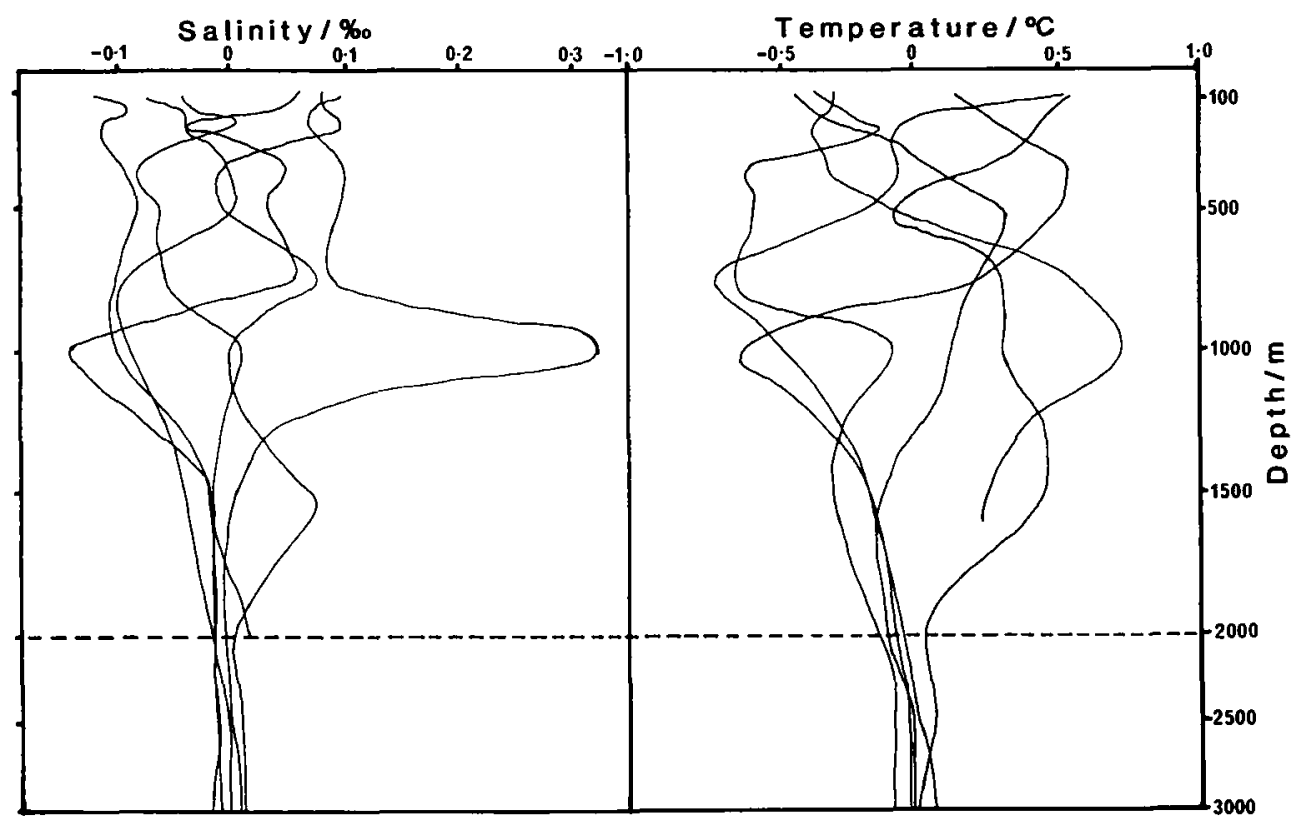

Fig. 2. Deviations from mean temperature and salinity values for 6 stations at $44^{\circ} 36^{\prime} \mathrm{N}$, $0^{\circ} 00^{\prime}$ W. (after Cooper, 1952). 
rence of living individuals. Where a sample was preserved on collection, rose Bengal solution was used to stain specimens which were living at the time of sample collection. All Murray Grab and Anchor Dredge samples contained living individuals and had therefore sampled the sediment surface. Unfortunately, none of the core top samples were preserved on collection. However, an analysis of the planktonic foraminiferal assemblages within these samples indicates that they were laid down under climatic conditions similar to those prevailing today (Chapter 7, Boltovskoy \& Wright, 1976), so that it is probable that the sediment surface has indeed been sampled.
Core top and Murray Crab samples represent a similar sampling area and volume. Anchor Dredges sample an unknown, but much larger, area of the sea floor. Precise quantitative data is therefore not directly comparable between Anchor Dredge and core top or Murray Grab samples. Watling et al. (1978) compared samples from grab and dredge samplers at $3 \mathrm{~m}$ and $25 \mathrm{~m}$ water depth. They found differences in the diversity, dominance and evenness of samples collected by the two different devices. They suggest that dredges act as an "averaging" device, counteracting biological patchiness to give a more suitable picture of the structure of a benthic community. Similar differences in diversity are seen between

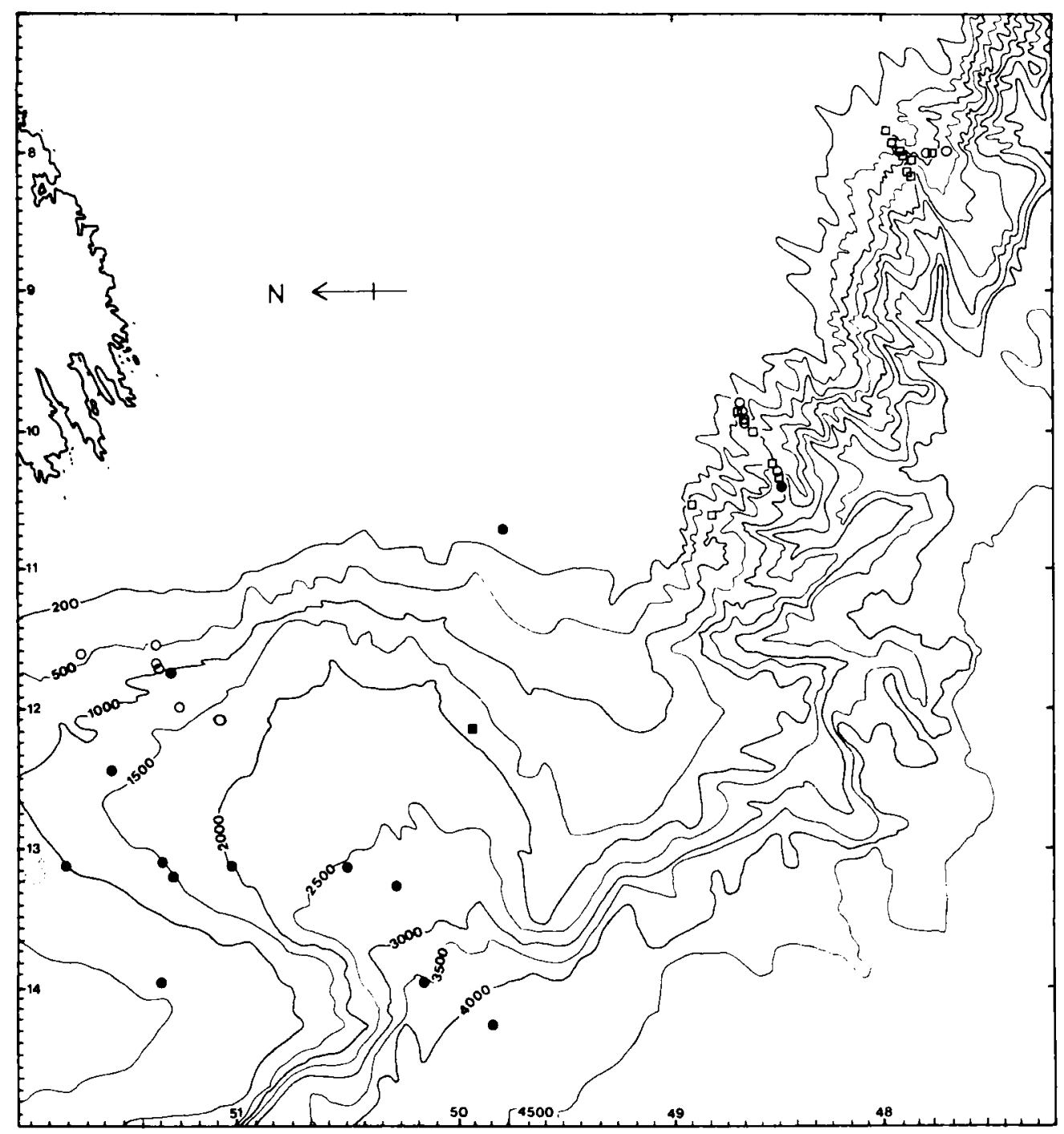

Fig. 3. Sample locations in the Porcupine Seabight area and on the SW Approaches continental margin.

Open symbols represent samples analysed for living and dead foraminifera and solid symbols those samples analysed for dead foraminifera only. Dots represent quantitative samples and squares non-quantitative samples. 
grab and dredge samples in this study, although patterns of dominance are very similar between the 2 types of sampler (Weston, 1982). It is felt in this study that careful control on the samples at the time of collection, together with an awareness of the limitations of the sampling devices, allows the use of quantitative data from samples taken by these different samplers.

The fraction studied is that $>125 \mu \mathrm{m}$. Some of the shallower samples (i.e. those from water depths $<500 \mathrm{~m}$ ) contain a large proportion of detrital material. To facilitate picking of these samples, a flotation of $\frac{1}{4}$ to $\frac{1}{2}$ of the sample was carried out using tetrachloromethane (see Weston, 1982).

\section{LIVING BENTHIC FORAMINIFERAL ASSEMBLAGES}

The Murray Grab collects a sample of known size $\left(100 \mathrm{~cm}^{3}\right)$ and can therefore be used to indicate approximate standing stocks of benthic foraminiferal assemblages ( $>125 \mu \mathrm{m}$ fraction). Although there are only half a dozen samples available for each area, they suggest the general worldwide trend for decreasing standing stocks downslope (Lutze, 1980), with highest numbers of living specimens being recorded at, or just below, the shelf break (Table 1).

WESTERN APPROACHES PORCUPINE SEABIGHT

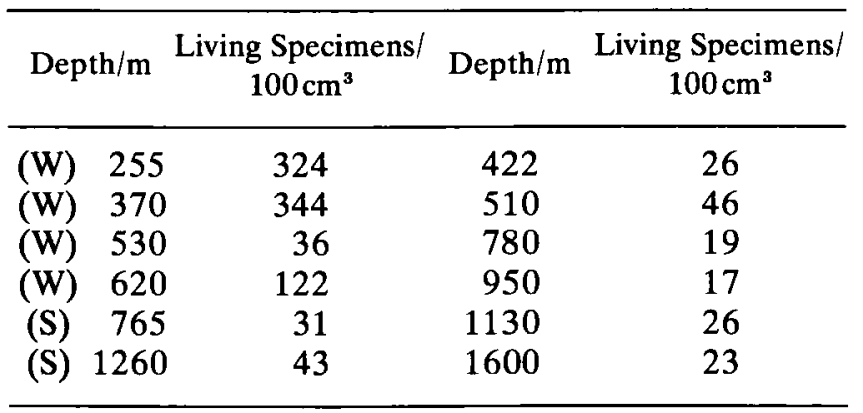

Table 1. Approximate standing stocks from Murray Grab samples,

$\mathrm{W}=$ Whittard Canyon

$\mathrm{S}=$ Shamrock Canyon

When samples from similar depths in the two areas are compared, values for standing stocks on the Western Approaches continental slope are at least twice those for the Porcupine Seabight. As the trend for decreasing standing stocks with increasing depth on the continental slope is thought to be due to a decrease in the available food with depth (Thiel, 1979, in Lutze, 1980), it is possible that more food is available in the energetic environment of the Western Approaches continental slope than in that of the less energetic eastern slope of the Porcupine Seabight.

Low values which do not fit in with this general trend are seen in both areas, particularly between approxi- mately $750 \mathrm{~m}$ and $1000 \mathrm{~m}$. Salinity and oxygen values taken at these depths (US National Oceanographic Data Center files) indicate that the nutrient-deficient core of the Mediterranean Water Mass is found at this level. The three samples in Table 1 from this level (Western Approaches: $765 \mathrm{~m}$, Porcupine Seabight: $780 \mathrm{~m}, 950 \mathrm{~m}$ ) are from areas where the overlying waters show not only maximum salinity and minimum oxygen values, but also maximum variability in these physical parameters (see Fig. 2).

At a similar level (approximately $700 \mathrm{~m}$ to $1400 \mathrm{~m}$ ), attached species such as Planulina ariminensis, Cibicides lobatulus, Cibicides refulgens and Paromalina crassa are found living on the Western Approaches continental slope and the eastern slope of the Porcupine Seabight (Table 2). Such species are more frequently associated with an outer shelf/upper slope environment (Murray, 1971). They also occur in living assemblages of samples from the shelf break to depths of about $500 \mathrm{~m}$. In upper slope samples the above species are (predominantly) found attached to pebbles. In samples from mid-slope depths, rather more variety is seen in the substrate utilised by attached forms. Species of Cibicides are found living attached to pebbles, a living Rhabdammina test, the leathery skins of ascidians and to shell debris. Planulina ariminensis and Paromalina crassa are found living attached to bundles of sponge spicules. $P$. ariminensis, together with another species, Osangularia rugosa, is also found attached to the thin, delicate tubes of an organism thought to be Rhabdopleura. Therefore, although present in shelf-break and mid-slope areas on the continental slope, attached species seem to make use of a greater variety of available substrates for attachment in the latter, deeper areas. Living assemblages of benthic foraminifera from the shelf-break and upper slope at $<500 \mathrm{~m}$ are similar in both the major areas analysed for living specimens. They are similar to those which are assigned to Group 4 of Sturrock \& Murray (1981) and occur in the deeper parts of the Western English Channel ( $>125 \mathrm{~m})$. They are composed largely of species such as Trifarina angulosa, Cassidulina obtusa, attached species such as Cibicides lobatulus and Gavelinopsis praegeri, together with abundant Cassidulina carinata and Brizalina spathulata. Assemblages from the shelf-break/uper slope samples also contain species associated with the muddier outer shelf areas of the Celtic Sea, e.g. Cancris auricula, and species more often associated with the inner shelf of the English Channel, e.g. Miliolinella circularis elongata (Murray, 1971).

However, as well as the difference in standing stocks between samples from the Porcupine Seabight and the Western Approaches continental slope, living foraminiferal faunas from $>500 \mathrm{~m}$ are also different. Species generally associated with the outer shelf and upper slope (e.g. Cassidulina carinata) are more abundant in living 


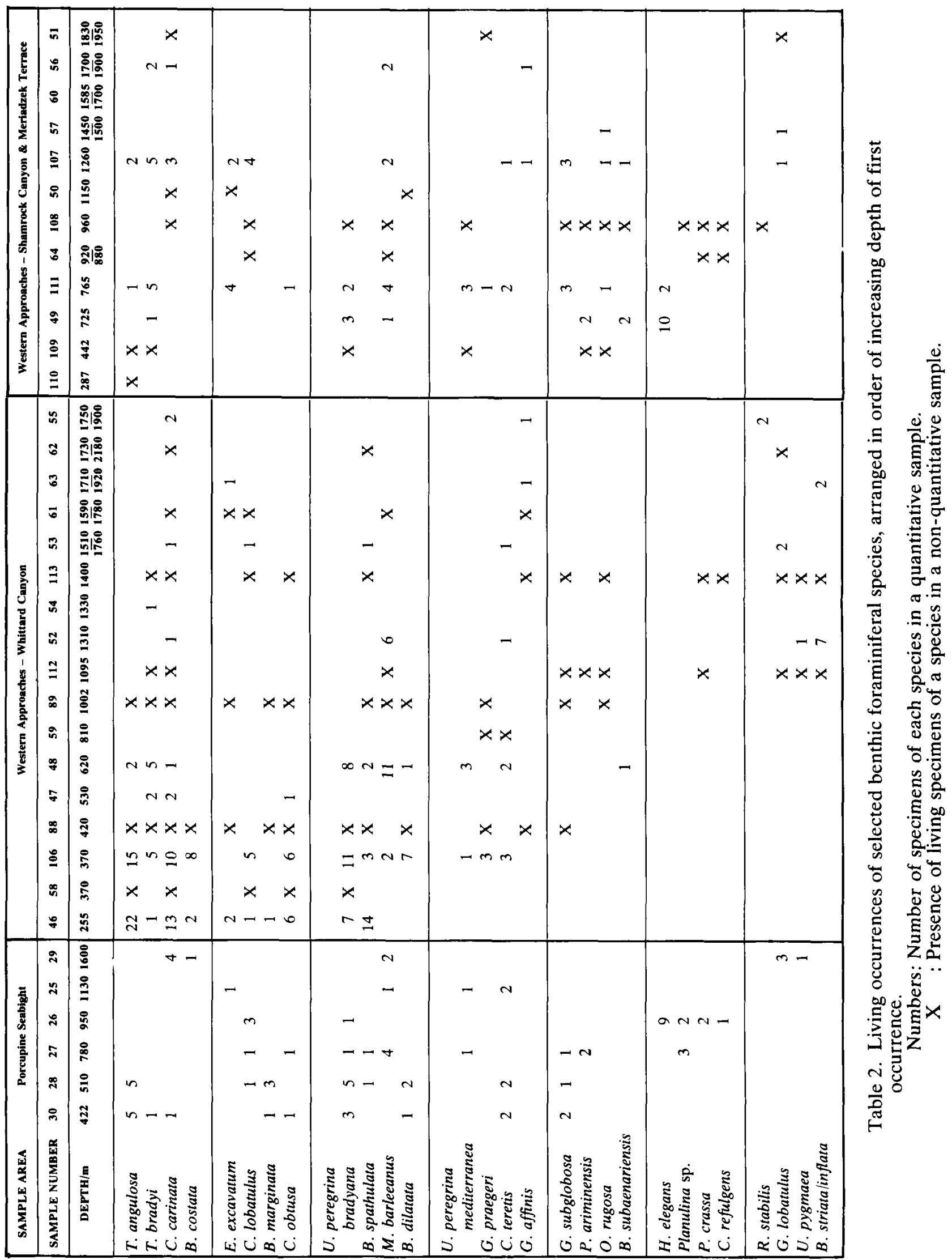


assemblages, and found at greater depth on the Western Approaches margin than on the eastern slope of the Porcupine Seabight. C. carinata is found living only at $422 \mathrm{~m}$ and $1600 \mathrm{~m}$ in the Porcupine Seabight samples, while in samples from the Western Approaches, living specimens of $C$. carinata are extremely abundant on the upper slope and persist to at least $2000 \mathrm{~m}$ water depth. Other species show a similarly extended depth distribution in living assemblages from the Western Approaches margin, e.g. Trifarina angulosa, $T$. bradyi and Brizalina spathulata. Brizalina subaenariensis is found living only in samples from the Western Approaches margin. Certain of the species named above are illustrated in Pl. 1 and 2.

\section{DEAD BENTHIC FORAMINIFERAL ASSEMBLAGES}

The distribution of living benthic foraminiferal species will, in many areas, be the single most important factor determining the distributions of species within the dead assemblages. However, the relative abundances of species within the living and dead assemblages will differ due to different rates of production of the various species (Murray, 1967, 1973, 1984). In samples from areas such as the abyssal plains (above the Calcite Compensation Depth), where secondary, postmortem alteration of assemblages is minimal, distributions of species within dead assemblages will be primarily determined by the occurrence and production of the living individuals. In samples from areas such as the continental slopes however, a major source of secondary alteration of dead assemblages will be downslope transportation processes.

Several lines of evidence indicate that downslope transport has little, if any, effect on samples from the Porcupine Seabight Area (Weston, 1982, in prep.). The Western Approaches continental margin, however, is very different. The distribution of many species is already extended downslope in this area relative to the Porcupine Seabight, and the effect of downslope reworking of dead tests is less easy to ascertain. In general, though, downslope reworking of tests $>125 \mu \mathrm{m}$ appears to be minimal. Tests transported from the shelf sea of the English Channel generally make up $<1 \%$ of the $>125 \mu \mathrm{m}$ fraction of samples (Murray et al, 1982). English Channel-derived sediment of 75 to $125 \mu \mathrm{m}$ size, however, makes up a large proportion of the fine sediment on the continental rise and abyssal plain (Murray et al., 1983). Downslope reworking of foraminiferal specimens on the continental slope itself is less easily recognised. Similar studies to those carried out on the Porcupine Seabight samples (Weston, 1982, in prep.) suggest that the main samples containing $>125 \mu \mathrm{m}$ allochthonous tests are again those of the lower continental slope and rise. In this study therefore, any samples which are obviously affected by downslope reworking of tests have been excluded from the quantitative analysis.

In both the study areas, there is a trend for increase in diversity of the assemblage with depth, to approximately $3500 \mathrm{~m}$. The increase occurs rapidly from the shelf (Fisher index $\alpha=5$ ) to the upper slope (approximately $750 \mathrm{~m}$ where $\alpha=10-20$ ), and then more slowly down to continental rise depths (Fig. 4). Samples from the Western Approaches continental slope tend to show higher diversities than those from the Porcupine Seabight. However, the anomalously high values recorded for the lower part of the Western Approaches continental slope probably relate more to the difference in sampling equipment (i.e. dredge rather than grab or corer) than to any ecological factor.

Similar differences to those seen in living assemblages are apparent between the two study areas. Dead assemblages from the Porcupine Seabight show a good zonation with relation to depth (Fig. 5 and Table 3), while those from the Western Approaches show little in the way of depth zonation. Species which dominate samples from the Porcupine Seabight (e.g. Uvigerina pygmaea and Gavelinopsis lobatulus) do occur in samples in the Western Approaches area, but usually represent only a relatively minor component of the latter. Dead assemblages from the Western Approaches are dominated by those species which were abundant in the living assemblages in this area: Cassidulina carinata, Brizalina spathulata, Brizalina dilatata and Brizalina subaenariensis (Pls. 1 and 2).

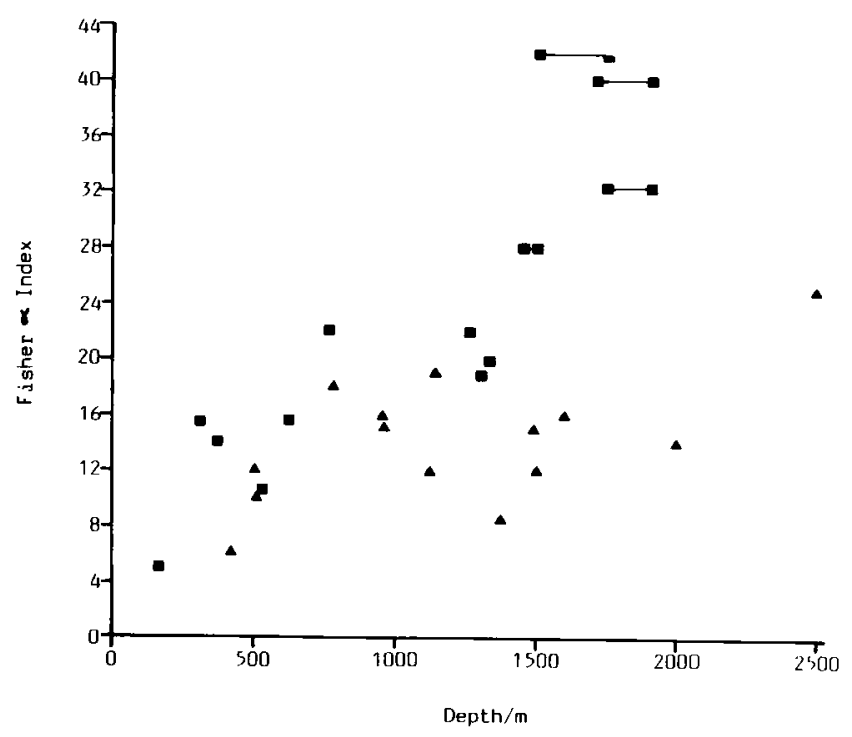

Fig. 4. Diversity (measured by the Fisher Index) plotted against sample depth. Symbols which are joined by a horizontal line represent dredge samples which span the relevant depths.

Squares: Western Approaches continental slope. Triangles: Porcupine Seabight. 


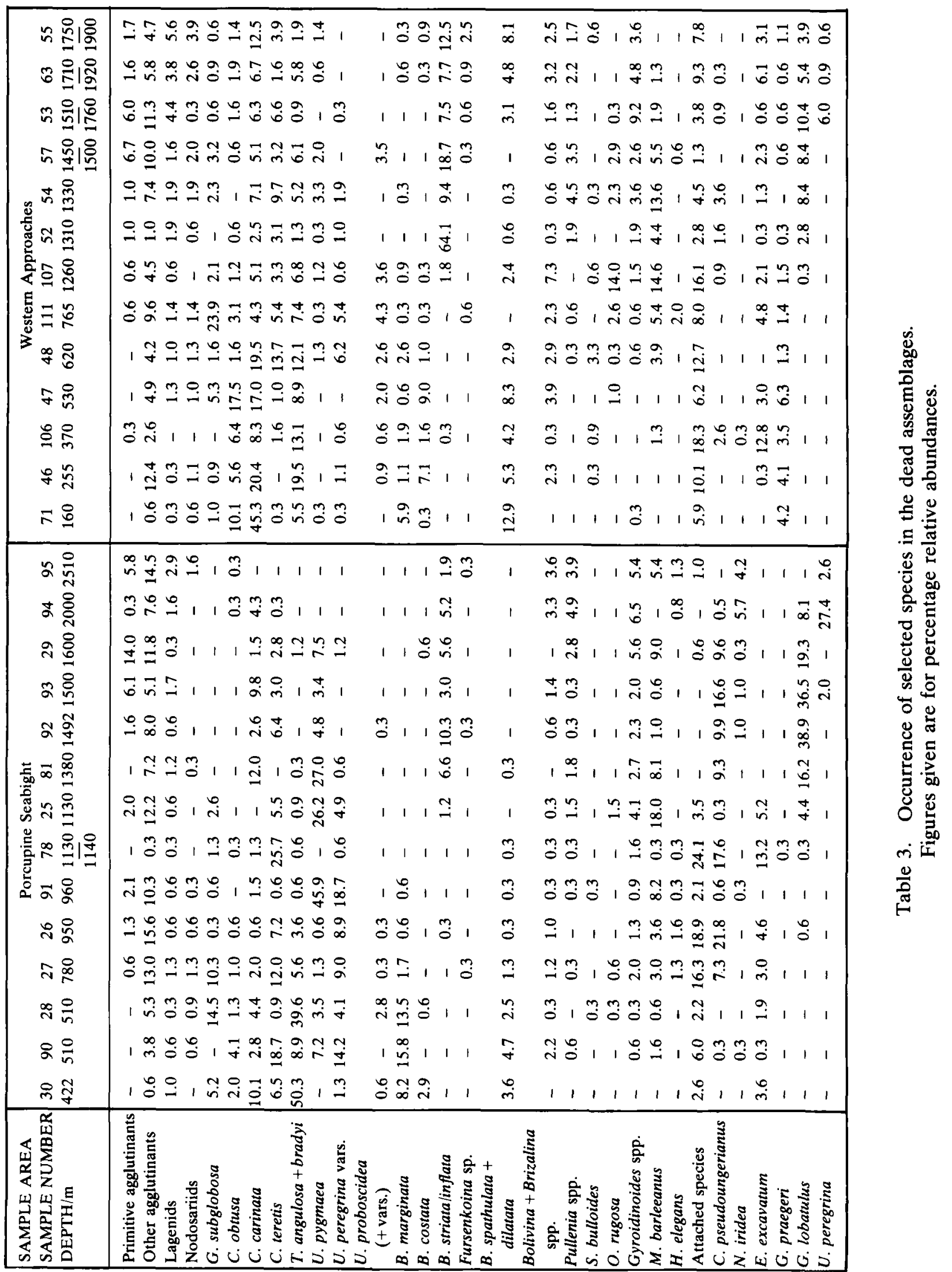




\section{VARIMAX FACTOR ANALYSIS}

In order to delineate major foraminiferal biofacies within the study areas, a Varimax Factor Analysis of all the quantitative dead assemblage data (31 samples) has been carried out (see Haq \& Lohmann, 1976 and Weston, 1982 for method). It was found necessary to extract 10 Varimax factors to account for $91 \%$ of the sample variance. These are listed, together with their important species components, in Table 4.

\begin{tabular}{cc}
\hline Factor & Important Species Components \\
\hline 1 & Cassidulina carinata \\
2 & Gavelinopsis lobatulus \\
& Cibicidoides pseudoungerianus \\
3 & Uvigerina pygmaea \\
4 & Attached species \\
& Cassidulina teretis \\
5 & Cibicidoides pseudoungerianus \\
& Complex agglutinants \\
6 & Melonis barleeanus \\
7 & Cassidulina obtusa \\
& Globocassidulina subglobosa \\
8 & Trifarina angulosa/Trifarina bradyi \\
Bulimina marginata \\
9 & Globocassidulina subglobosa \\
& Bulimina striata/inflata group \\
& Osangularia rugosa \\
10 & Melonis barleeanus \\
Attached species
\end{tabular}

Table 4. Important species components (in order of decreasing importance) in each of the factors derived from the Varimax Factor Analysis.

FACTOR 1: This represents an assemblage dominated by Cassidulina carinata. It is characteristic of samples from the Celtic Sea shelf edge and the upper and lower slope of Whittard Canyon (Fig. 6). In these lower slope samples, Factor 1 is co-dominant with Factor 8 (see below) and it is possible that its occurrence here is due to the effects of downslope transport in this area, despite every effort to exclude samples so affected. (All samples excluded from analysis on the grounds that they contain large quantities of allochthonous material, give high loadings on Factor 1 when a comparative data analysis is carried out (Weston, 1982)). It is probable that the C. carinata assemblage described by Factor 1 represents the active environment of the shelf-edge to upper slope. (Unfortunately, shelf-edge to upper slope depths have not been sampled quantitatively in the Shamrock Canyon in this study, due to ensnarement and loss of one.Murray Grab in this area. From comparison with assemblages from the Whittard Canyon, and non quantitative samples from the upper slope of Shamrock Canyon, it is probable that assemblages from the latter area would also be dominated by Factor 1).

FACTOR 2: Gavelinopsis lobatulus is the important species component in this factor. It is particularly characteristic of assmblages from $1350-1600 \mathrm{~m}$ in the Porcupine Seabight and Whittard Canyon (Fig. 6). This reflects the extremely consistent depth relationship shown by $G$. lobatulus on this part of the North European continental slope. Reasons for this consistency are not known but temperature may exert some influence on the species distribution.

FACTOR 3: The dominant species component of this factor is Uvigerina pygmaea. This factor is important only in the Porcupine Seabight at depths of approximately $1000 \mathrm{~m}$ (Fig. 6).

FACTOR 4: The assemblage represented by this Varimax Factor is composed mainly of the attached species component (e.g. Cibicides lobatulus, Cibicides refulgens, Rupertina stabilis) although Cassidulina teretis and Cibicidoides pseudoungerianus are also important. It is

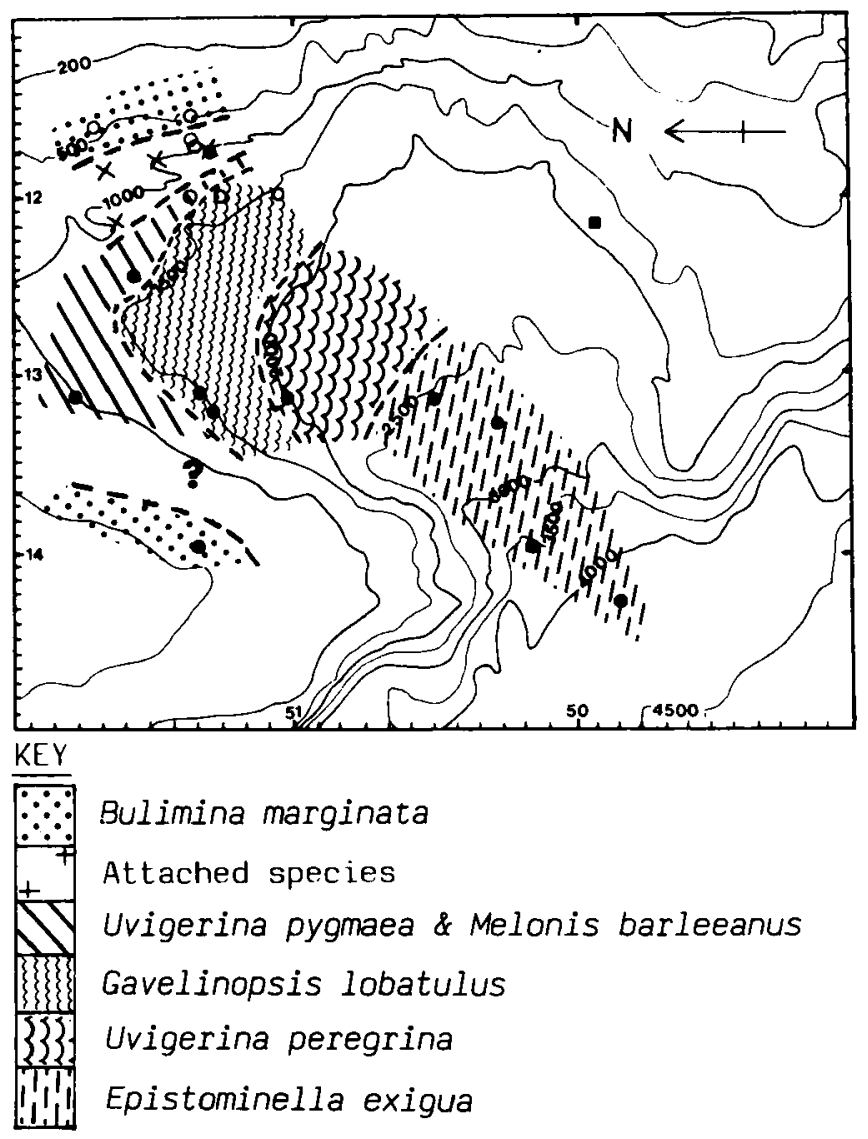

Fig. 5. Zonation of samples from the Porcupine Seabight area using the dominant species of dead assemblages. 
dominant in samples from $500 \mathrm{~m}$ to $1000 \mathrm{~m}$ on the northeastern slope of the Porcupine Seabight and is codominant with Factor 7 (see below) on the Porcupine Bank at $510 \mathrm{~m}$. As discussed previously under the section on living foraminiferal assemblages, this factor may reflect colonisation of relatively variable environments by eurytopic species more usually associated with shallower depths.

FACTOR 5: Varimax Factor 5 represents an assemblage dominated by the "complex agglutinants" species component, and is rather variable in nature. Its distribution among the 31 samples analysed by this paper suggests that it predominates in samples taken from areas essentially on the border between the deep and intermediate water masses.

FACTOR 6: This Varimax Factor defines an assemblage composed predominantly of Cassidulina obtusa and Globocassidulina subglobosa. It is co-dominant in two samples from the Western Approaches upper continental slope: $765 \mathrm{~m}$ on the Meriadzek Terrace and $530 \mathrm{~m}$ in the Whittard Canyon. It is noticeable that both of these samples gave very low values for standing stocks (see Table 1). Assemblages similar to these also occur at intermediate depths in open ocean areas of the Northeastern Atlantic (Weston, 1982). Such areas would be subject to a relatively low food supply and fairly variable oceanographic conditions. The upper slope would also be subject to exceedingly variable environmental conditions with respect to such ecological parameters as food-supply, bottom water characteristics and substrate (Rex, 1976). It is possible that the two samples from the Western Approaches area in which Factor 6 is codominant are areas of variable conditions and low food supply where cosmopolitan and opportunistic species such as $C$. obtusa and especially $G$. subglobosa have been able to colonise the continental slope biotope. FACTOR 7: This Varimax Factor assemblage is composed mainly of the Trifarina angulosa $/ T$. bradyi species

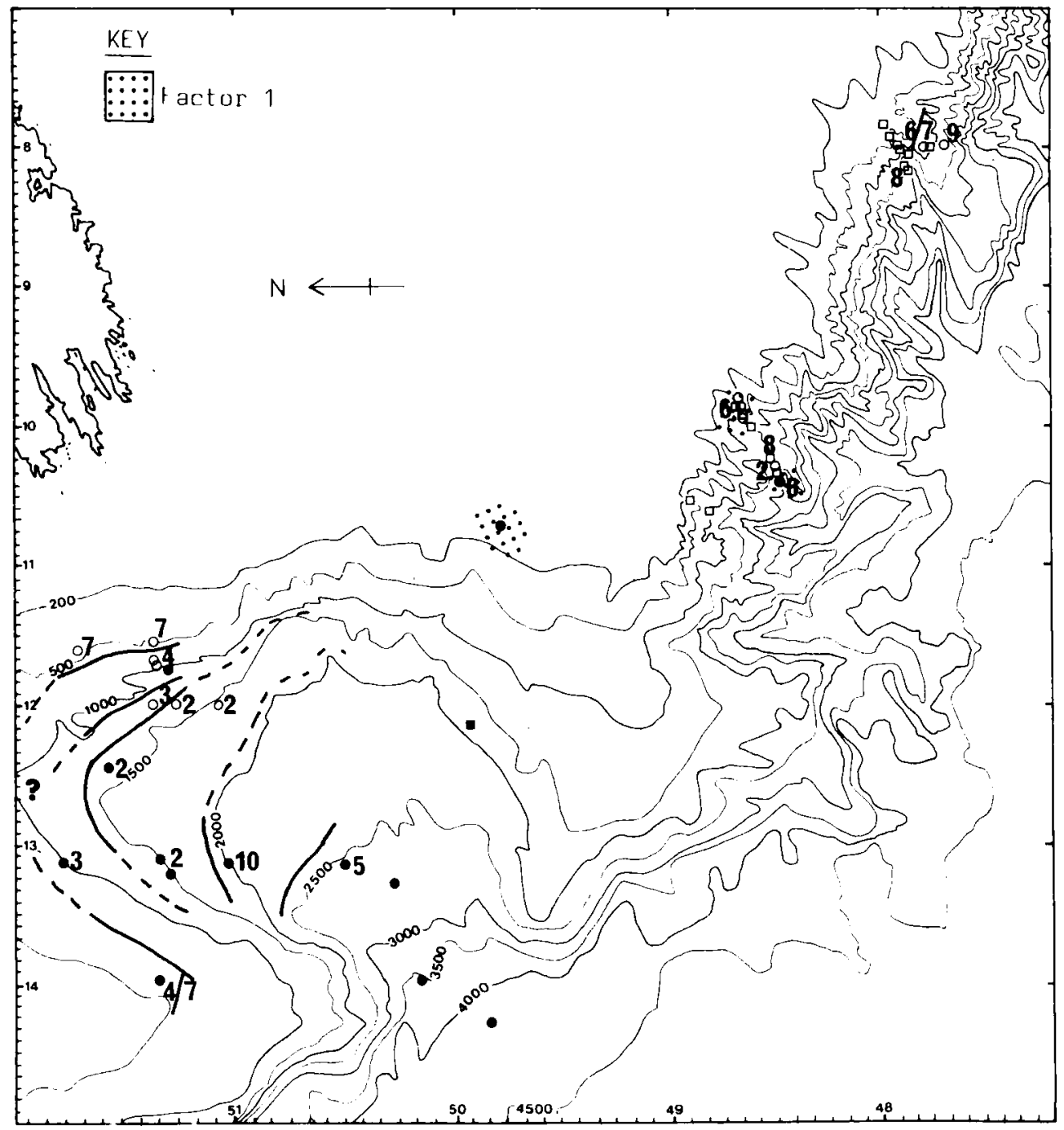

Fig. 6. Distribution of the dominant factors from the Varimax Factor Analysis. 
component, with Bulimina marginata and G. subglobosa as subsidiary components. It is dominant in all samples from $<550 \mathrm{~m}$ in the Porcupine Seabight. Factor 7 appears to be representative of samples from relatively low energy, upper slope areas, while Factor 1 dominates samples from the more energetic, upper submarine canyon environment.

FACTOR 8: The species component made up of the Bulimina striata/inflata plexus is dominant in Varimax Factor 8. It is particularly important in samples from middle to lower slope depths in both the Whittard and Shamrock Canyons. Samples from these depths in the Porcupine Seabight are dominated by Factor 2 assemblages (i.e. Gavelinopsis lobatulus). As individual species, B. striata/inflata and $G$. lobatulus have very similar patterns of depth distribution on the European continental slope (Weston, 1982). However, they appear to show an inverse pattern of dominance. It is possible that the overall distributions of these species are influenced by similar oceanographic variables (e.g. temperature), while secondary influences determine their abundance within that range. In this case, $G$. lobatulus shows a preference for the quieter, muddier, rather more stable conditions of the Porcupine Seabight, while $B$. striata/inflata prefers the more variable, more energetic and probably sandier environment of the submarine canyons.

FACTOR 9: Osangularia rugosa is the dominant species component in this Varimax Factor and Factor 9 is important in only one sample: that from $1260 \mathrm{~m}$ on the Meriadzek Terrace. The overall distribution of $O$. rugosa in Recent sediments is very similar to the distribution of Mediterranean Water and $O$. rugosa is particularly important in samples taken from the approximate depths of the core of this water mass (Weston, 1982). In the Porcupine Seabight, Uvigerina pygmaea and Factor 3 occupy the areas overlain by this core (see above and Fig. 6 ). It may be that these two factor assemblages are indicative of similar oceanographic conditions (i.e. occurrence of the core of Mediterranean Water or contour currents), but that they occur in areas of differing sedimentary substrate.

FACTOR 10: The dominant species component of Varimax Factor 10 is Uvigerina peregrina. This factor is important in only one sample: that from $2000 \mathrm{~m}$ in the Porcupine Seabight. The occurrence of $U$. peregrina on the Northwestern Atlantic continental slope has been shown to be related to maximum values of organic carbon and silt in the substrate (Miller and Lohmann, 1982). Although such properties have not been measured in this study, sediments from lower slope - upper rise depths (i.e. approximately $2000 \mathrm{~m}$ ) are often particularly rich in organic matter and silt (Rowe \& Haedrich, 1979). It is therefore possible that $U$. peregrina (and therefore Factor 10) have their distribution related to the above factors.
This factor analysis therefore delineates some of the major differences between dead benthic foraminiferal assemblages from the two main study areas which have been touched on in the previous pages. It emphasises the well-zoned depth distributions of the Porcupine Seabight, and the more cosmopolitan nature of the faunas in the Whittard and Shamrock Canyons. It also emphasises the differences in the actual assemblage compositions in the two areas. These major differences are summarised in Fig. 7.

\section{DISCUSSION}

This comparison of living and dead foraminiferal faunas from the Western Approaches and Porcupine Seabight continental slopes indicates some of the differences in the distribution and abundance of benthic foraminiferal species which may result from different hydrographic and sedimentological settings. Similar differences have been reported in other studies. By comparison with the distributions recorded in this study, some factors which might influence the distribution of various benthic foraminiferal species can be suggested.

The greater abundance and extended depth distribution of living specimens of Cassidulina carinata in the Western Approaches area is paralleled on parts of the African continental margin (Lutze, 1980; Haake, 1980: In Lutze (1980), $C$. laevigata $=C$. carinata of this study). $C$. carinata is most abundant in the living assemblages of two traverses from Lutze's study, between $22^{\circ} \mathrm{N}$ and $15^{\circ} \mathrm{N}$. In these areas, it is present to depths of approx. $2000 \mathrm{~m}$ (Weston, 1982). However, only two living specimens of $C$. carinata are found in Lutze's other traverse taken at $26^{\circ} \mathrm{N}$. The former two traverses (B and C) are taken in areas of rich food supply due to upwelling between $19^{\circ} \mathrm{N}$ and $22^{\circ} \mathrm{N}$, and discharge of the Senegal River between $14^{\circ} \mathrm{N}$ and $17^{\circ} \mathrm{N}$; the latter, Traverse $A$, is situated in an area of low food supply due to the winnowing effect of undercurrents (Lutze, 1980).

Other species which show increased abundance and/ or extended depth distribution in living assemblages from the Western Approaches area, e.g. Brizalina dilata and Brizalina spathulata, are more difficult to relate to Lutze's study as both these species appear to have been grouped under the name Bolivina ex. gr. dilatata. However, the living occurrence of the Bolivina dilatata group of Lutze is restricted to his traverses $B$ and $C$ and extends to around $1000 \mathrm{~m}$ in this area. Brizalina subaenariensis also occurs living only in Traverse $\mathrm{C}$ of Lutze. In the work of Haake (1980), similar trends are seen in the distribution of these three species on the African continental slope off Gambia and Senegal (12$14^{\circ} \mathrm{N}$ ). Here, the maximum occurrence of $C$. carinata in the living assemblages is at $900 \mathrm{~m}$ in a traverse at $12.5^{\circ} \mathrm{N}$, and this coincides with the only living occurrence of Brizalina subaenariensis and with maxima in the living occurrences of Uvigerina peregrina dirupta and 


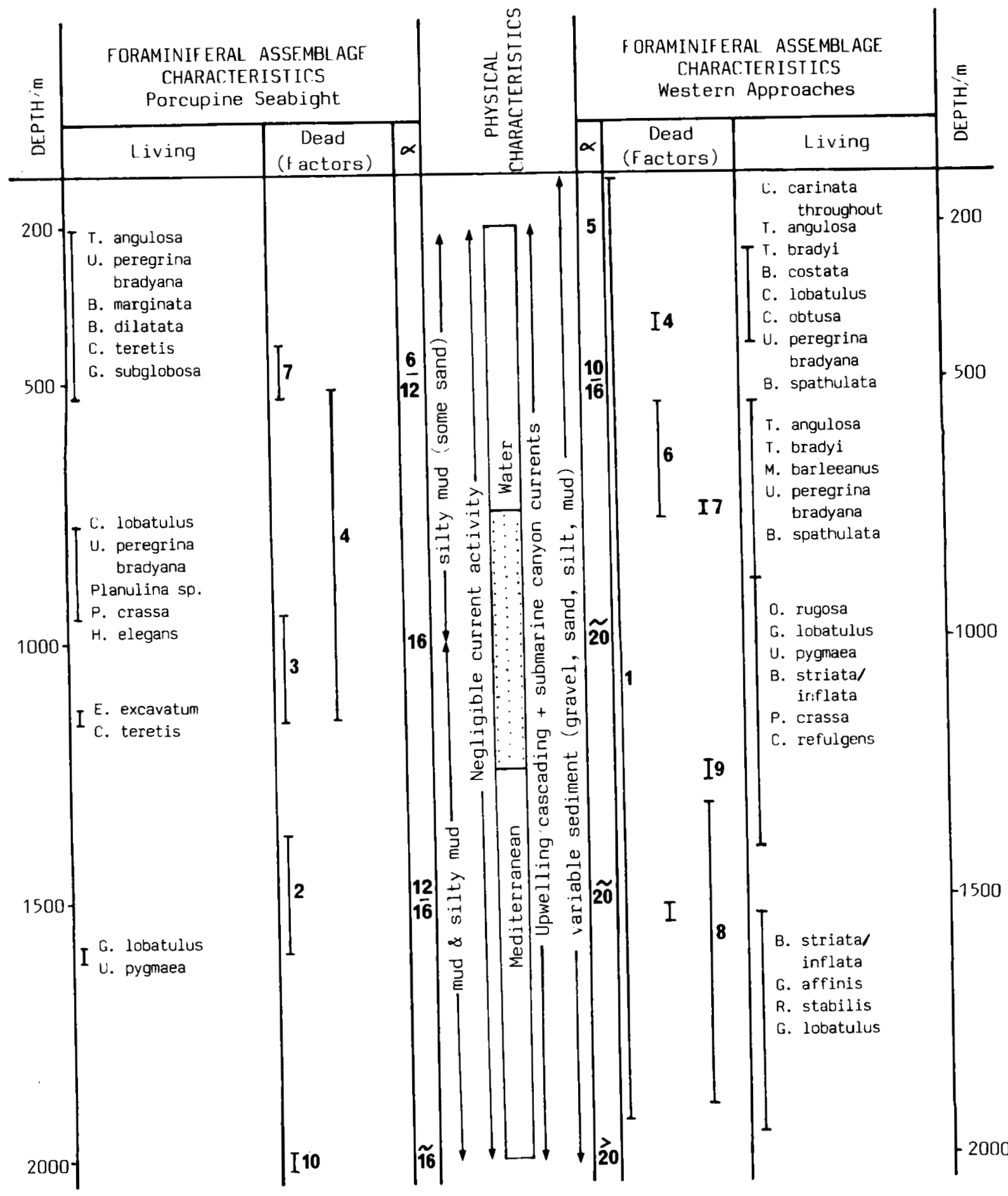

Mediterranean Water core

Fig. 7. Summary of the main characteristics of the foraminiferal assemblages from the Porcupine Seabight and Western Approaches continental slopes. 
Globobulimina turgida. Species such as the latter are often associated with organic rich sediments (Miller \& Lohmann, 1982). Haake's traverse at $12.5^{\circ} \mathrm{N}$ is situated due west of a large river and may therefore represent an area with a relatively high food supply in the same way as Traverse $\mathrm{C}$ at $15-16^{\circ} \mathrm{N}$ in the study of Lutze. Bolivina subaenariensis (= Brizalina subaenariensis of this study) is also described from an unusual dead assemblage on the North Florida continental slope by Sen Gupta et al. (1981). B. subaenariensis is generally rare in the Western Atlantic, but in this assemblage, it occurs in unusually high abundance in a sample which has a very high clay-silt, organic carbon and hydrocarbon content. Sen Gupta et al. link this anomalous occurrence to periodic upwelling in the area enabling this species to flourish.

It is large, heavy tests of species such as $B$. subaenariensis and $B$. dilatata which, together with $C$. carinata, characterise the difference between assemblages from the Western Approaches margin and the Porcupine Seabight. In a study carried out by Hendrix (1958), species of benthic foraminifera with large, heavy tests were found to be more abundant in areas of medium grained sediments with generally low clay and low free-carbon contents. Hendrix concluded that a large, heavy test may be an adaptation to life in a relatively high density, high velocity environment. In flume studies carried out by Kontrovitz et al. (1978), it was found that $B$. subaenariensis tests, of all those tested, have the highest traction velocities. Therefore, $B$. subaenariensis (and, by inference, similar species which may have a large, heavy test such as $\boldsymbol{B}$. dilatata) would be ideally suited to life in a relatively high velocity environment, such as that which might exist in a submarine canyon.

In the study of Sen Gupta et al. (1981), and certain samples from the study of Lutze (1980), the occurrence of $C$. carinata with B. dilatata and B. subaenariensis appears to be related to samples from fine grained, organic rich sediments. This suggests that these species predominate in areas with a rich food supply. In samples from this study, the relationship appears to be a little more complicated. These species are found to characterise samples from the submarine canyons of the Western Approaches continental slope. Such species have tests ideally adapted to colonising such a high velocity environment, while the alternating diurnal canyon currents and infrequent turbidity currents would increase the supply of nutrients and food to the benthic environment.

Despite the major differences between the overall assemblages, certain species of benthic foraminifera have a very constant depth distribution in both living and dead assemblages across the Western Approaches continental slope into the Porcupine Seabight, although their relative abundances in the two areas vary markedly (e.g. Gavelinopsis lobatulus). The upper depth limit of
G. lobatulus in this study is at approximately $1000 \mathrm{~m}$, and it extends down to a depth of about $2000 \mathrm{~m}$, with its maximum abundance at around $1450-1500 \mathrm{~m}$ in the Porcupine Seabight. In samples from the African Continental Margin and open ocean areas of the Northeastern Atlantic, $G$. lobatulus also occurs in samples within the depth range of 1000-2000 m (Weston, 1982). Comparison of these results with the study of Lutze (1980) is difficult because he does not record $G$. lobatulus from his samples. However, he does record Gavelinopsis translucens and this is morphologically very similar to G. lobatulus. G. translucens is recorded between $500 \mathrm{~m}$ and $1500 \mathrm{~m}$ in Lutze's Traverses $A$ and $B\left(26-22^{\circ} \mathrm{N}\right)$, and between $500 \mathrm{~m}$ and $1000 \mathrm{~m}$ in Traverse $C\left(16^{\circ} \mathrm{N}\right)$. In a study by Seiler (1973) on samples from the continental slope off Portugal $\left(36^{\circ} \mathrm{N}\right.$ and $\left.40^{\circ} \mathrm{N}\right)$, Gavelinopsis praegeri (forma $\mathrm{B}$ ) is recorded. The illustrations of this form are of specimens which would have been referred to G. lobatulus here. G. praegeri (forma B) occurs in Seiler's profiles between approximately $1000 \mathrm{~m}$ and $2200 \mathrm{~m}$, with maximum relative abundances being recorded at $1460 \mathrm{~m}$.

The depth distribution of G. lobatulus (as defined in this study) therefore appears to follow a very regular pattern: North of the Strait of Gibraltar, it has a constant depth distribution between approximately $1000 \mathrm{~m}$ and $2000 \mathrm{~m}$, with maximum relative abundances at around the centre of this zone. South of the Strait of Gibraltar Lutze's data suggest that this depth zone distribution rises about $500 \mathrm{~m}$. This distribution pattern is rather similar to the distribution of temperature within the Northeastern Atlantic.

Species such as Trifarina bradyi also show a very interesting distribution pattern when data from this study and others in the Northeastern Atlantic are combined. T. bradyi is found in living and dead assemblages from the shelf break to $1130 \mathrm{~m}$ in the Porcupine Seabight and to about $2000 \mathrm{~m}$ in the Western Approaches area. Maximum living abundances in the Western Approaches samples occur at around $900-1000 \mathrm{~m}$. In dead assemblages, $T$. bradyi often makes up $>5 \%$ in the Western Approaches samples, while it never makes up $>1 \%$ in samples from the Porcupine Seabight. In Seiler's (1975) study from the Portuguese continental slope, $T$. bradyi is recorded from living and dead assemblages between $200 \mathrm{~m}$ and $2220 \mathrm{~m}$ in the traverse from approximately $40^{\circ} \mathrm{N}$, and between $400 \mathrm{~m}$ and $1710 \mathrm{~m}$ in that from approximately $36^{\circ} \mathrm{N}$. Again, maximum living abundances of $T$. bradyi are recorded at around $900-1000 \mathrm{~m}$. Further south, in the study carried out by Lutze (1980), $T$. bradyi is found only in Traverse A (at approximately $26^{\circ} \mathrm{N}$ ) between the depths of $200 \mathrm{~m}$ and $1100 \mathrm{~m}$. It is absent from Lutze's Traverses B and C further to the south, and also from Haake's (1980) samples off Senegal and Gambia. Apart from the samples from the Western Approaches continental slope, $T$. bradyi never becomes 
an important component of the dead assemblage, comprising as it does only $1-2 \%$ of the assemblage. However, the overall distribution of $T$. bradyi presents an interesting pattern. The area between Traverses $A$ and $B$ in Lutze's study is the approximate position of the transition from South Atlantic Water in the south to Mediterranean Water in the north. Also, the core of Mediterranean Water lies at approximately $1000 \mathrm{~m}$ in much of the Northeastern Atlantic and this is the level at which maxima in the living abundances of $T$. bradyi have been recorded. Therefore, the overall distribution of T. bradyi is very similar to that of Mediterranean Water in the Northeastern Atlantic.

Another set of species which, as indicated above, appear to have their distribution related to that of Mediterranean Water, is species with an attached mode of life (e.g. Cibicides lobatulus, Cibicides refulgens, Planulina ariminensis and Paromalina crassa). In this study, such species were found living attached to various substrates at depths between $700 \mathrm{~m}$ and $1400 \mathrm{~m}$ on the Northeastern slope of the Porcupine Seabight and in the Western Approaches area. They also show fairly high relative abundances in the dead assemblages between $950 \mathrm{~m}$ and $1250 \mathrm{~m}$ in these two areas. Similar peaks in the abundances of attached species such as $C$. lobatulus have been recorded by several workers along the European continental slope of the Northeastern Atlantic between approximately $700 \mathrm{~m}$ and $1500 \mathrm{~m}$ (Caralpet al., 1970; Pujos, 1970; Pujos-Lamy, 1973). Pujos (1970) suggested that these species show a distribution related to the presence of the core of Mediterranean Water. This suggestion is strengthened by the results from this study. It is possible that these eurytopic species usually associated with outer shelf/upper slope environments are able to colonise areas of the continental slope which have become unfavourable to species more usually associated with middle slope depths due to the high variability, high salinity or low oxygen concentrations of the Mediterranean Water core. Considering the highly variable nature of the core of Mediterranean Water (see Fig. 2), it seems most likely that it is this variability in the environment which is important.

The results of this study and others therefore suggest certain features of the environment which might strongly influence the distribution of some benthic foraminiferal species on the continental slopes. The influencing factors suggested here include food availability, bottom current activity, temperature, occurrence of bottom water masses and various properties related to these, i.e. variability of the core of Mediterranean Water.

\section{CONCLUSIONS}

1. Despite their geographic proximity, the Western Approaches continental margin and that of the
Porcupine Seabight support widely differing benthic foraminiferal faunas.

2. Although showing the world wide trend of decreasing standing stocks downslope, standing stocks in the two areas differ greatly. Those from the Western Approaches margin are much higher than those from the Porcupine Seabight. This could be related to the availability of food as it is probable that more food would be available in the energetic Western Approaches slope environment.

3. Living and dead benthic foraminiferal assemblages from the two areas are different. Large robust forms of Brizalina and Cassidulina are more abundant in the Western Approaches area. Also most species appear to have a broad depth range of occurrence in this area. In comparison, assemblages from the Porcupine Seabight area show a good zonation with respect to depth.

4. These results suggest that, as in other areas, foraminiferal distribution and abundance on the continental slope may only be secondarily related to depth, while factors such as temperature, substrate, variability in the characteristics of the bottom water and food availability may be the primary controlling factors.

\section{ACKNOWLEDGEMENTS}

The author would like to thank Drs. A. J. and E. C. Southward and Dr. G. Mardell of the MBA, Plymouth for the provision of samples and ships time; the crew of R.V. Sarsia for their patient help; Dr. R. Kidd and Dr. P. Weaver of IOS, Wormley for the provision of samples; NERC for the research studentship under which this work was carried out; Prof. J. W. Murray for his help and advice and SSI Limited. The manuscript was kindly read and critically appraised by Dr. L. M. Sheppard. Hypotype specimens of the illustrated species are lodged at the British Museum (Natural History).

\section{REFERENCES}

Boltovskoy, E. \& Wright, R. 1976. Recent Foraminifera, 515 pp. Dr. W. Junk. b.v., Publishers.

Caralp, M., Lamy, A. \& Pujos, M. 1970. Contribution a la connaissance de la distribution bathymetrique des foraminiferes dans le Golfe de Gascogne, Revta esp. Micropaleont., 2, 55-84.

Cooper, L. H. N. 1952. Physical and chemical oceanography of the waters bathing the continental slope of the Celtic Sea. $J$. mar. biol. Ass. U.K., 30, 465-510.

Cooper, L. H. N. \& Vaux, D. 1949. Cascading over the continental slope of water from the Celtic Sea.J. mar. biol. Ass. U.K., 28, 719-750.

Day, A. A. 1959. The continental slope between Brittany and Ireland. Deep Sea Res., 5, 249-265.

Haake, F.-W. 1980. Benthische Foraminiferen in OberflachenSedimenten und Kernen des Ostatlantiks vor Senegal/ Gambia (Westafrika), 'Meteor' Forschungsergeb., C32, 1-29. 
Heaps, N. S. 1980. A mechanism for local upwelling along the European continental slope. Oceanol. Acta, 3, 449-454.

Hendrix, W. E. 1958. Foraminiferal shell form, a key to sedimentary environment. J. Paleont., 38, 87-89.

Herman, Y. 1981. Paleoclimatic and paleohydrologic record of Mediterranean Deep Sea cores based on pteropods, planktonic and benthic foraminifera. Revta esp. Micropaleont., 13, 171-200.

Kenyon, N. H., Belderson, R. H. \& Stride, A. H. 1978. Channels, canyons and slump folds on the continental slope between SW Ireland and Spain. Oceanol. Acta, 1, 369-380.

Kontrovitz, M. K., Snyder, S. W. \& Brown, R. J. 1978. A flume study of the movement of foraminiferid tests. Palaeogeogr., Palaeoclimatol., Palaeoecol., 23, 141-151.

Lutze, G. F. 1980. Depth distribution of benthic foraminifera on the continental margin off NW Africa. 'Meteor' Forschungsergeb., C23, 31-80.

Mart, Y., Auffret, G. A., Auzende, J. M. \& Pastouret, L. 1979. Geological observations from a submersible dive on the Western continental slope of the Armorican Massif. Mar. Geol., 31, M61-M68.

Menzies, R. J., George, R. Y. \& Rowe, G. T. 1973. Abyssal environment and ecology of the world oceans, 480 pp. John Wiley \& Sons, N.Y.

Miller, K. G. \& Lohmann, G. P. 1982. Environmental distribution of Recent benthic foraminifera on the Northeast U.S. continental slope. Bull geol. Soc. Am., 93, 200-206.

Murray, J. W. 1967. Production in benthic foraminiferids. $J$. nat. Hist., 1, 61-68.

Murray, J. W. 1971. An Atlas of British Recent Foraminiferids, 244 pp. Heinemann, London.

Murray, J. W. 1973. Distribution and Ecology of Living Benthic Foraminiferids, 274 pp. Heinemann, London.

Murray, J. W. 1984. Benthic Foraminifera: some relationships between ecological observations and palaeoecological interpretations. Benthos '83, 2nd Int. Symp. Benthic Foraminifera (Pau, April 1983), 465-469.

Murray, J. W., Sturrock, S. \& Weston, J. 1982. Suspended load transport of foraminiferal tests in a tide- and wave-swept sea. J. Foramin. Res., 12, 51-65.

Murray, J. W., Weston, J. F. \& Sturrock, S. 1983. Sedimentary indicators of water movement in the western approaches to the English Channel. Cont. Shelf Res., 1, 339-352.

Owen, T. R. 1974. The Geology of the Western Approaches. In Nairn, A. E. M. \& Stehli, F. G. (Eds.), The Ocean Basins and Margins. 2. The North Atlantic, 233-272.

Pingree, R. D. \&. Mardell, G. T. 1981. Slope turbulence, internal waves and phytoplankton growth at the Celtic Sea shelf break. Phil. Trans. R. Soc. Lond., A302, 663-682.

Pujos, M. 1970. Influence des eaux de type mediterranean sur la repartitions de certains foraminiferes benthiques dans le Golfe de Gascogne. Cah. oceanogr., 22, 827-831.

Pujos-Lamy, A. 1973. Repartition bathymetrique des foraminiferes benthiques profonds du Golfe de Gascogne. Comparaison avec d'autres aires oceaniques. Revta esp. Micropaleont., 5, 213-234.

Rex, M. A. 1976. Biological accommodation in the deep sea benthos: comparative evidence on the importance of predation and productivity. Deep Sea Res., 23, 975-987.

Rowe, G. T. \& Haedrich, R. L. 1979. The biota and biological processes of the continental slope. In Doyle, L. H. \& Pilkey, O. H. (Eds.), Geology of the Continental Slopes. Spec. Publs. Soc. econ. Palaeont. Miner., Tulsa, 27, 49-59.
Seiler, W. C. 1973. Tiefenverteilung benthischer Foraminiferen am portugiesischen Kontinentalhang. PhD. thesis, Kiel, Germany, 107 pp.

Seiler, W. C. 1975 . Tiefenverteilung benthischer Foraminiferen am portugiesischen Kontinentalhang. 'Meteor' Forschungsergeb., C 23, 47-94.

Sen Gupta, B. K., Lee, R. F. \& May, M. S. 1981. Upwelling and an unusual assemblage of benthic foraminifera on the northern Florida continental slope. J. Paleont., 55, 853857.

Shepard, F. P. 1973. Submarine Geology, 3rd ed., 517 pp, Harper and Row Publ.

Shepard, F. P., Marshall, N. F., McLoughlin, P. A. \& Sullivan, G. G. 1979. Currents in Submarine Canyons and other Seavalleys, AAPG Studies in Geology, 8, 171 pp, Tulsa, Oklahoma.

Sturrock, S. \& Murray, J. W. 1981. Comparison of low energy and high energy marine middle shelf foraminiferal faunas; Celtic Sea and western English Channel. In Neale, J. W. and Brasier, M. D., Microfossils from Recent and Fossil Shelf Seas. Ellis Horwood Ltd., Chichester, 250-260 for British Micropalaeontological Society.

Watling, L., Kinner, P. C. \& Maurer, D. 1978. The use of species abundance estimates in marine biological studies. J. Exp. Mar. Biol. and Ecol., 35, 109-118.

Weston, J. F. 1982.Distribution and Ecology of Recent deep sea benthic Foraminifera in the northeast Atlantic Ocean. Unpubl. PhD. Thesis, University of Exeter, 442 pp.

Weston, J. F. (in prep.) Downslope transport of foraminiferal tests on the European continental slope. 


\section{Explanation of Plate 1}

Fig. 1. Brizalina dilatata (Reuss). Sample $46(\times 140)$.

Fig. 2. Brizalina spathulata (Williamson). Sample $11(\times 137)$.

Fig. 3. Brizalina subaenariensis (Cushman). Sample $10(\times 115)$.

Fig. 4. Trifarina angulosa (Williamson). Sample $22(\times 132)$.

Fig. 5. Trifarina bradyi Cushman. Sample $9(\times 105)$.

Fig. 6. Uvigerina pygmaea d'Orbigny. Sample $25(\times 123)$.

Fig. 7. Uvigerina peregrina Cushman. Sample $11(\times 84)$.

Fig. 8. Bulimina marginata d'Orbigny. Sample $15(\times 259)$.

Fig. 9. Bulimina inflata end-member of the $B$. inflata/striata group. Sample $11(\times 115)$.

Fig. 10. Bulimina striata end-member of the $B$. inflata/striata group. Sample $9(\times 203)$.

Fig. 11. Cassidulina carinata (Silvestri). Sample $9(\times 235)$. 


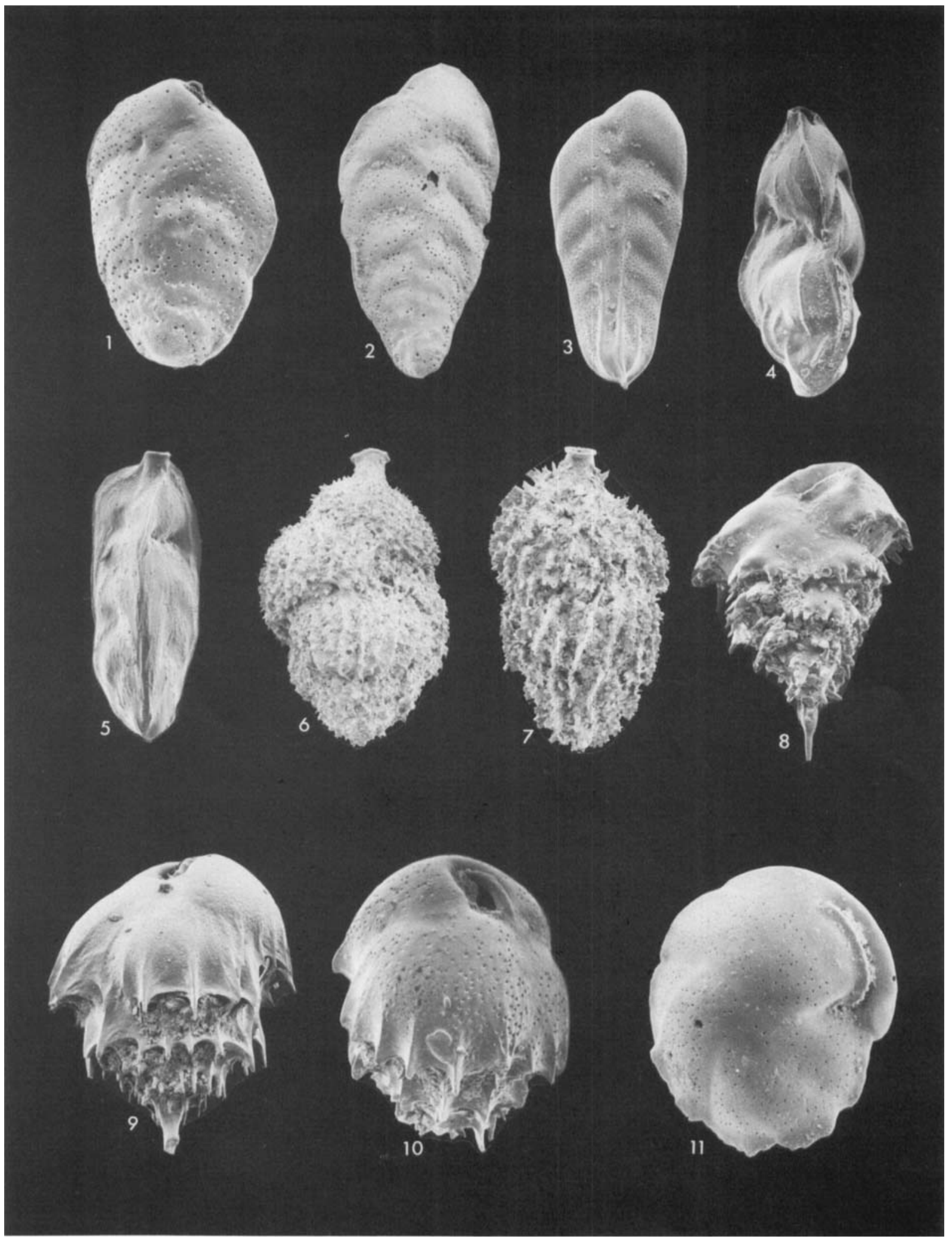




\section{Explanation of Plate 2}

Fig. 1. Globocassidulina subglobosa (Brady). Sample $18(\times 245)$.

Fig. 2. Gavelinopsis lobatulus (Parr). Umbilical side. Sample $8(\times 315)$.

Fig. 3. Gavelinopsis lobatulus (Parr). Spiral side. Sample $8(\times 295)$.

Fig. 4. Melonis barleeanus (Williamson). Side view. Sample $25(\times 133)$.

Fig. 5. Planulina ariminensis d'Orbigny. Sample $64(\times 98)$.

Fig. 6. Cikicides lobatulus (Walker \& Jacob). Oblique view. Sample $8(\times 79)$.

Fig. 7. Paromalina crassa (Cushman). Side view. Sample $26(\times 67)$.

Fig. 8. Cibicides refulgens Montfort. Oblique view. Sample $26(\times 102)$.

Fig. 9. Paromalina crassa (Cushman) living attached to a sponge spicule. Sample $112(\times 102)$.

Fig. 10. Paromalina crassa (Cushman). Dorsal view. Sample $26(\times 76)$.

Fig. 11. Osangularia rugosa (Phleger \& Parker) and Planulina ariminensis d'Orbigny living attached to a thin ?Rhabdopleura tube. Sample $108(\times 133)$. 


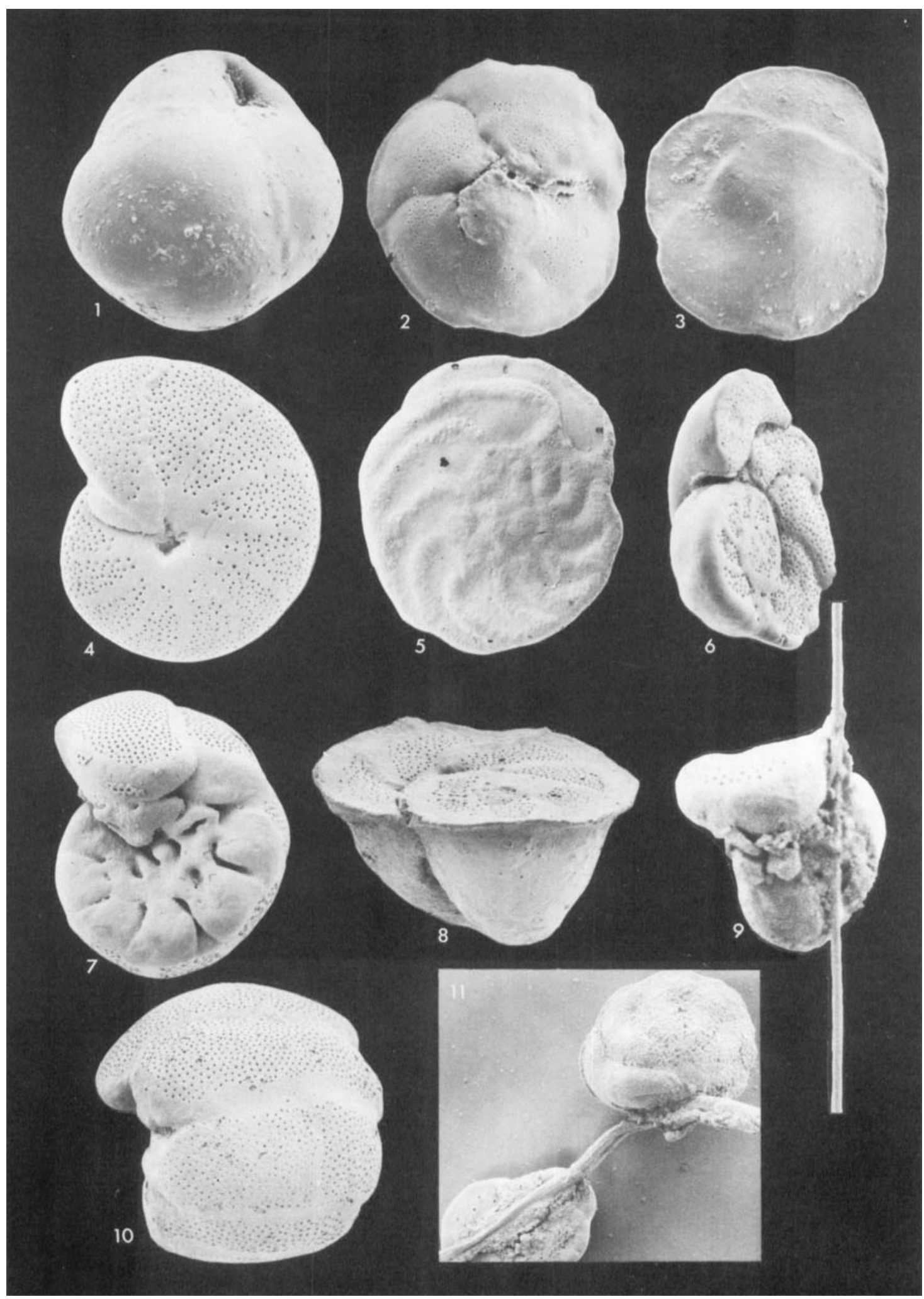

